\title{
LEVEL II SCOUR ANALYSIS FOR BRIDGE 36 (BRIDTH00050036) on TOWN HIGHWAY 5, crossing BRIDGEWATER HOLLOW BROOK, BRIDGEWATER, VERMONT
}

U.S. Geological Survey Open-File Report 96-387

Prepared in cooperation with

VERMONT AGENCY OF TRANSPORTATION and

FEDERAL HIGHWAY ADMINISTRATION 


\section{LEVEL II SCOUR ANALYSIS FOR}

BRIDGE 36 (BRIDTH00050036) on

TOWN HIGHWAY 5, crossing

BRIDGEWATER HOLLOW BROOK,

BRIDGEWATER, VERMONT

By SCOTT A. OLSON and ERICK M. BOEHMLER

U.S. Geological Survey

Open-File Report 96-387

Prepared in cooperation with

VERMONT AGENCY OF TRANSPORTATION

and

FEDERAL HIGHWAY ADMINISTRATION 


\title{
U.S. DEPARTMENT OF THE INTERIOR BRUCE BABBITT, Secretary
}

\author{
U.S. GEOLOGICAL SURVEY \\ Gordon P. Eaton, Director
}

For additional information write to:

District Chief

U.S. Geological Survey 361 Commerce Way

Pembroke, NH 03275
Copies of this report may be purchased from:

U.S. Geological Survey Earth Science Information Center Open-File Reports Section Box 25286, MS 517 Federal Center

Denver, CO 80225 


\section{CONTENTS}

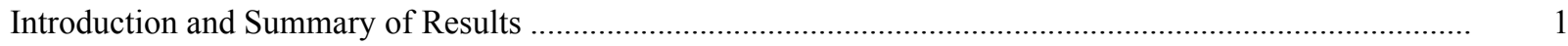

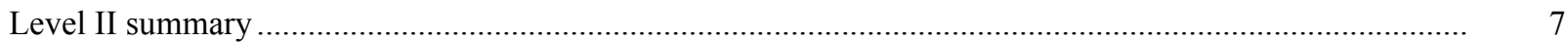

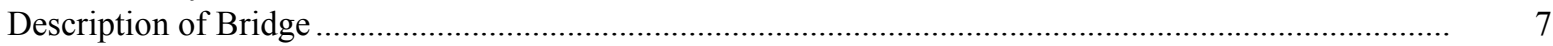

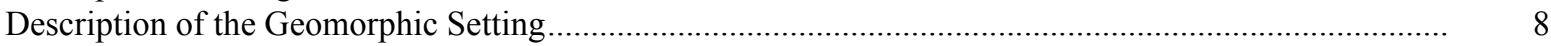

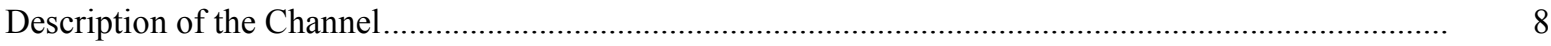

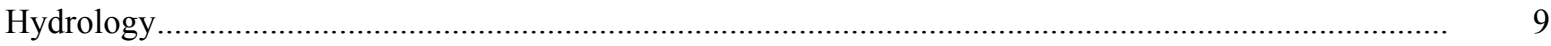

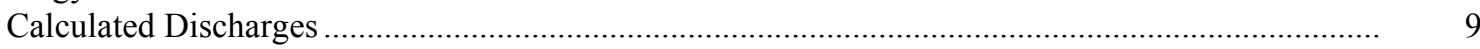

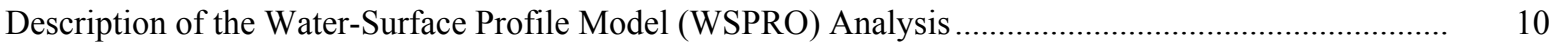

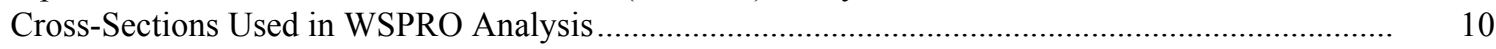

Data and Assumptions Used in WSPRO Model ...................................................................... 11

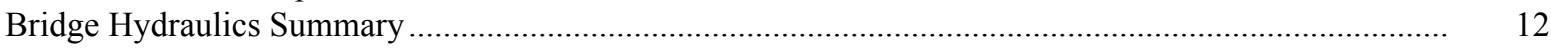

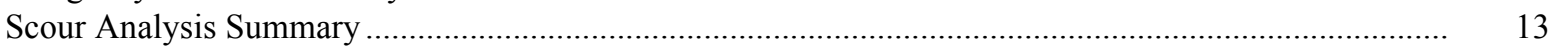

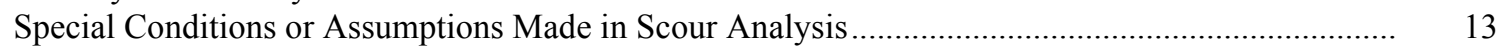

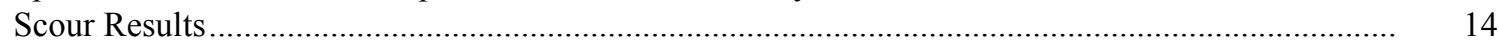

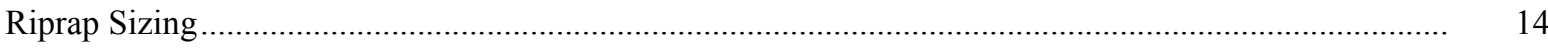

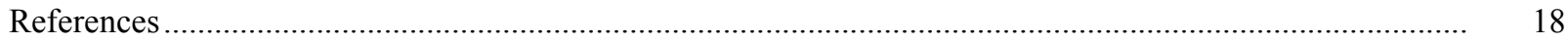

Appendixes:

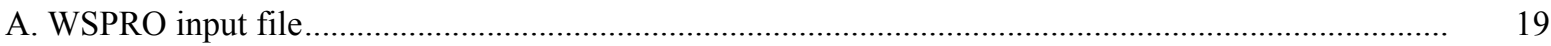

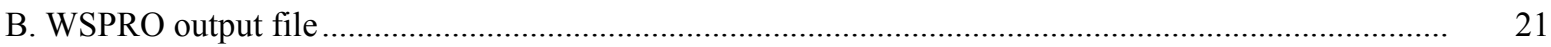

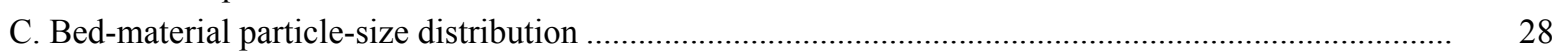

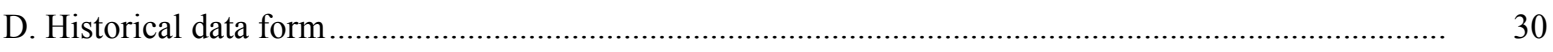

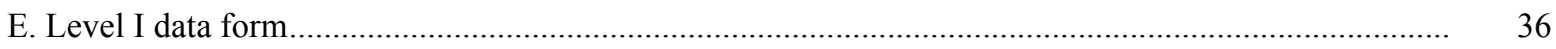

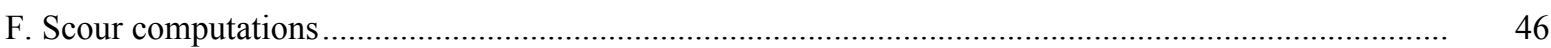

\section{FIGURES}

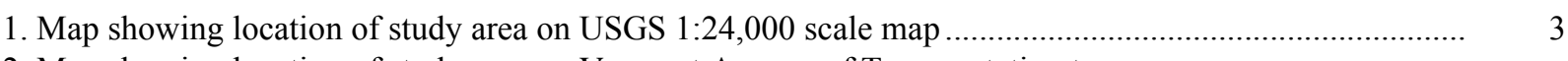

2. Map showing location of study area on Vermont Agency of Transportation town
highway map

3. Structure BRIDTH00050036 viewed from upstream (November 2, 1994) .............................................. 5

4. Downstream channel viewed from structure BRIDTH00050036 (November 2, 1994)......................... 5

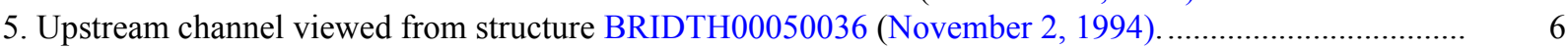

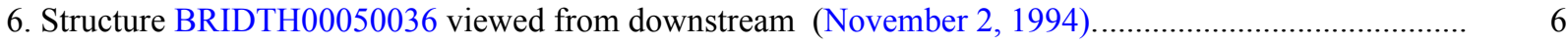

7. Water-surface profiles for the 100- and 500-year discharges at structure

BRIDTH00050036 on Town Highway 5, crossing Bridgewater Hollow Brook,

Bridgewater, Vermont.

8. Scour elevations for the 100- and 500-year discharges at structure

BRIDTH00050036 on Town Highway 5, crossing Bridgewater Hollow Brook,

Bridgewater, Vermont.

\section{TABLES}

1. Remaining footing/pile depth at abutments for the 100-year discharge at structure BRIDTH00050036 on Town Highway 5, crossing Bridgewater Hollow Brook,

Bridgewater, Vermont

2. Remaining footing/pile depth at abutments for the 500-year discharge at structure

BRIDTH00050036 on Town Highway 5, crossing Bridgewater Hollow Brook,

Bridgewater, Vermont.

3
5
5
6
6




\begin{tabular}{|c|c|c|}
\hline Multiply & By & To obtain \\
\hline \multicolumn{3}{|c|}{ Length } \\
\hline inch (in.) & 25.4 & millimeter (mm) \\
\hline foot $(\mathrm{ft})$ & 0.3048 & $\operatorname{meter}(\mathrm{m})$ \\
\hline mile (mi) & 1.609 & kilometer (km) \\
\hline \multicolumn{3}{|c|}{ Slope } \\
\hline foot per mile ( $\mathrm{ft} / \mathrm{mi})$ & 0.1894 & meter per kilometer $(\mathrm{m} / \mathrm{km})$ \\
\hline \multicolumn{3}{|c|}{ Area } \\
\hline square mile $\left(\mathrm{mi}^{2}\right)$ & 2.590 & square kilometer $\left(\mathrm{km}^{2}\right)$ \\
\hline \multicolumn{3}{|c|}{ Volume } \\
\hline cubic foot $\left(\mathrm{ft}^{3}\right)$ & $\begin{array}{l}0.02832 \\
\text { Velocity and Flow }\end{array}$ & cubic meter $\left(\mathrm{m}^{3}\right)$ \\
\hline foot per second $(\mathrm{ft} / \mathrm{s})$ & 0.3048 & meter per second $(\mathrm{m} / \mathrm{s})$ \\
\hline cubic foot per second $\left(\mathrm{ft}^{3} / \mathrm{s}\right)$ & 0.02832 & cubic meter per second $\left(\mathrm{m}^{3} / \mathrm{s}\right)$ \\
\hline $\begin{array}{l}\text { cubic foot per second per } \\
\text { square mile } \\
{\left[\left(\mathrm{ft}^{3} / \mathrm{s}\right) / \mathrm{mi}^{2}\right]}\end{array}$ & 0.01093 & $\begin{array}{l}\text { cubic meter per } \\
\text { second per square } \\
\text { kilometer }\left[\left(\mathrm{m}^{3} / \mathrm{s}\right) / \mathrm{km}^{2}\right]\end{array}$ \\
\hline
\end{tabular}

OTHER ABBREVIATIONS

$\begin{array}{lrlr}\mathrm{BF} & \text { bank full } & \text { LWW } & \text { left wingwall } \\ \mathrm{cfs} & \text { cubic feet per second } & \text { MC } & \text { main channel } \\ \mathrm{D}_{50} & \text { median diameter of bed material } & \text { RAB } & \text { right abutment } \\ \mathrm{DS} & \text { downstream } & \text { RABUT } & \text { face of right abutment } \\ \mathrm{elev} & \text { elevation } & \text { RB } & \text { right bank } \\ \mathrm{f} / \mathrm{p} & \text { flood plain } & \text { ROB } & \text { right overbank } \\ \mathrm{ft} & \text { square feet } & \text { RWW } & \text { right wingwall } \\ \mathrm{ft} / \mathrm{ft} & \text { feet per foot } & \text { TH } & \text { town highway } \\ \mathrm{JCT} & \text { junction } & \text { UB } & \text { under bridge } \\ \mathrm{LAB} & \text { left abutment } & \text { US } & \text { upstream } \\ \mathrm{LABUT} & \text { face of left abutment } & \text { USGS } & \text { United States Geological Survey } \\ \text { LB } & \text { left bank } & \text { VTAOT Vermont Agency of Transportation } \\ \text { LOB } & \text { left overbank } & \text { WSPRO } & \text { water-surface profile model }\end{array}$

In this report, the words "right" and "left" refer to directions that would be reported by an observer facing downstream. Sea level: In this report, "sea level" refers to the National Geodetic Vertical Datum of 1929-- a geodetic datum derived from a general adjustment of the first-order level nets of the United States and Canada, formerly called Sea Level Datum of 1929.

In the appendices, the above abbreviations may be combined. For example, USLB would represent upstream left bank. 


\title{
LEVEL II SCOUR ANALYSIS FOR BRIDGE 36 (BRIDTH00050036) ON TOWN HIGHWAY 5, CROSSING BRIDGEWATER HOLLOW BROOK, BRIDGEWATER, VERMONT
}

\author{
By Scott A. Olson and Erick M. Boehmler
}

\section{INTRODUCTION AND SUMMARY OF RESULTS}

This report provides the results of a detailed Level II analysis of scour potential at structure BRIDTH00050036 on town highway 5 crossing Bridgewater Hollow Brook, Bridgewater, Vermont (figures 1-8). A Level II study is a basic engineering analysis of the site, including a quantitative analysis of stream stability and scour (U.S. Department of Transportation, 1993). Results of a Level I scour investigation also are included in Appendix E of this report. A Level I investigation provides a qualitative geomorphic characterization of the study site. Information on the bridge, gleaned from Vermont Agency of Transportation (VTAOT) files, was compiled prior to conducting Level I and Level II analyses and is found in Appendix D.

The site is in the Green Mountain section of the New England physiographic province of central Vermont. The $3.60-\mathrm{mi}^{2}$ drainage area is in a predominantly forested basin. In the vicinity of the study site, the banks have dense woody vegetation coverage.

In the study area, Bridgewater Hollow Brook has an incised, sinuous channel with a slope of approximately $0.028 \mathrm{ft} / \mathrm{ft}$, an average channel top width of $24 \mathrm{ft}$ and an average channel depth of $4 \mathrm{ft}$. The predominant channel bed material is cobble $\left(\mathrm{D}_{50}\right.$ is $196 \mathrm{~mm}$ or $\left.0.644 \mathrm{ft}\right)$. The geomorphic assessment at the time of the Level I and Level II site visit on November 2, 1994, indicated that the reach was stable.

The town highway 5 crossing of Bridgewater Hollow Brook is a 30-ft-long, one-lane bridge consisting of one 27-foot steel-beam span (Vermont Agency of Transportation, written communication, August 25,1994$)$. The bridge is supported by vertical, concrete abutments with wingwalls. The channel is skewed approximately 30 degrees to the opening and the opening-skew-to-roadway is also 30 degrees.

The scour protection measures at this site were sparse type- 2 stone fill (less than 36 inches diameter) along both abutments, upstream wingwalls, and the downstream left wingwall and type-1 stone fill (less than 12 inches diameter) along the downstream right wingwall. Additional details describing conditions at the site are included in the Level II Summary and Appendices D and E. 
Scour depths and rock rip-rap sizes were computed using the general guidelines described in Hydraulic Engineering Circular 18 (Richardson and others, 1995). Total scour at a highway crossing is comprised of three components: 1) long-term streambed degradation; 2) contraction scour (due to accelerated flow caused by a reduction in flow area at a bridge) and; 3) local scour (caused by accelerated flow around piers and abutments). Total scour is the sum of the three components. Equations are available to compute depths for contraction and local scour and a summary of the results of these computations follows.

There was no contraction scour for all modelled flows. Abutment scour ranged from 4.9 to $7.0 \mathrm{ft}$. The worst-case abutment scour occurred at the 500-year discharge. Additional information on scour depths and depths to armoring are included in the section titled "Scour Results". Scoured-streambed elevations, based on the calculated scour depths, are presented in tables 1 and 2. A cross-section of the scour computed at the bridge is presented in figure 8. Scour depths were calculated assuming an infinite depth of erosive material and a homogeneous particle-size distribution.

It is generally accepted that the Froehlich equation (abutment scour) gives "excessively conservative estimates of scour depths" (Richardson and others, 1995, p. 47). Usually, computed scour depths are evaluated in combination with other information including (but not limited to) historical performance during flood events, the geomorphic stability assessment, existing scour protection measures, and the results of the hydraulic analyses. Therefore, scour depths adopted by VTAOT may differ from the computed values documented herein. 


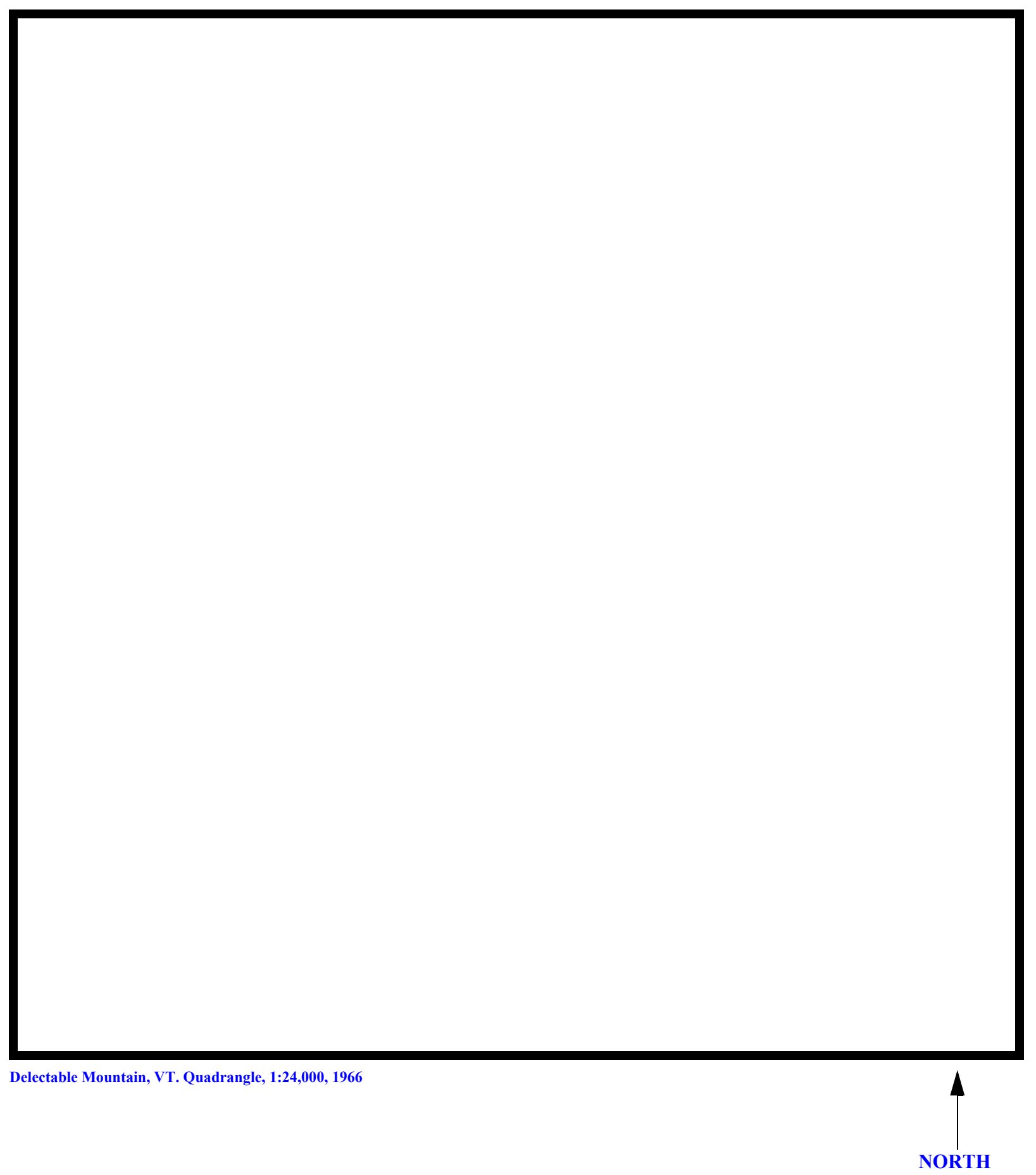

Figure 1. Location of study area on USGS 1:24,000 scale map. 
Figure 2. Location of study area on Vermont Agency of Transportation town highway map. 

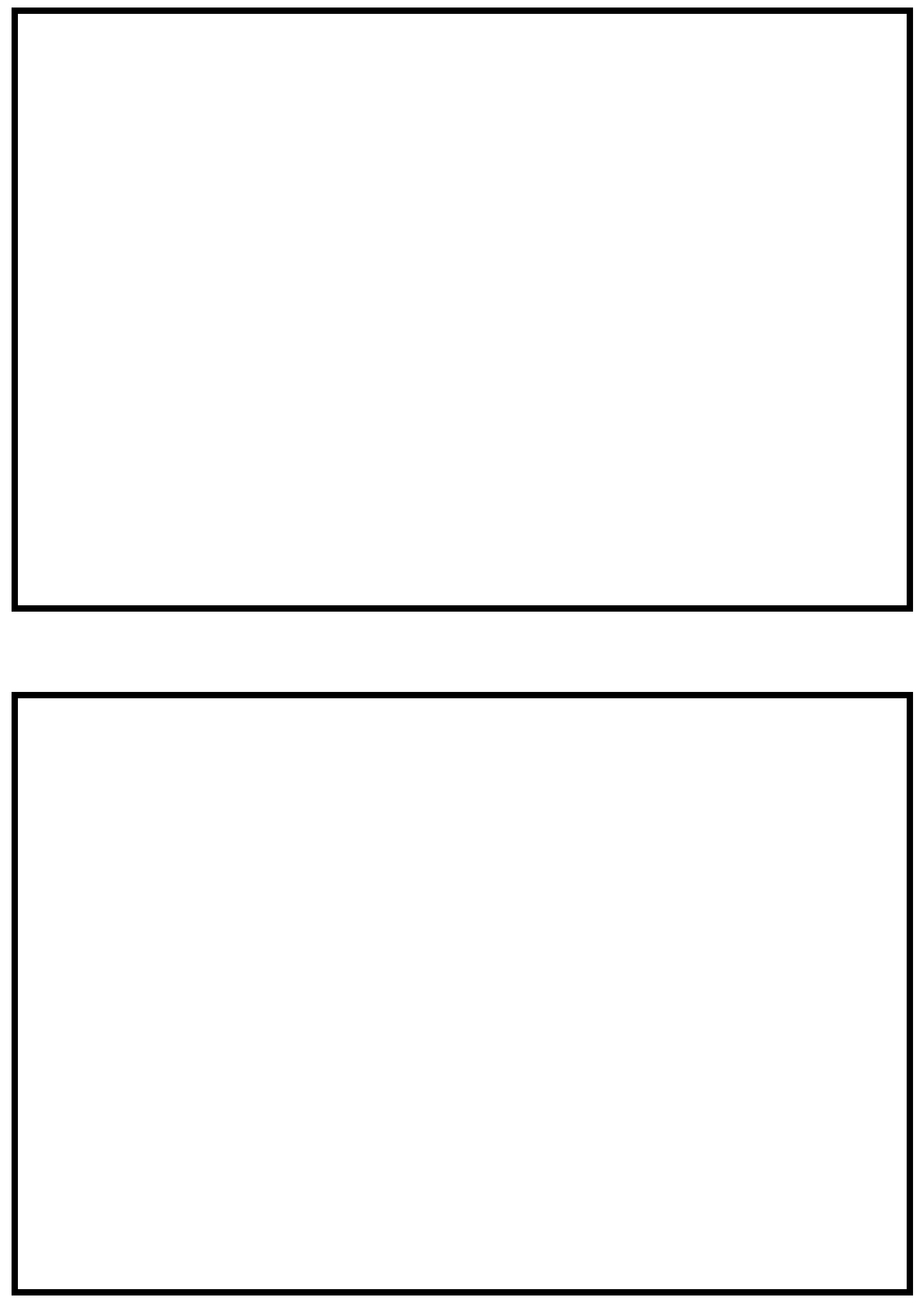

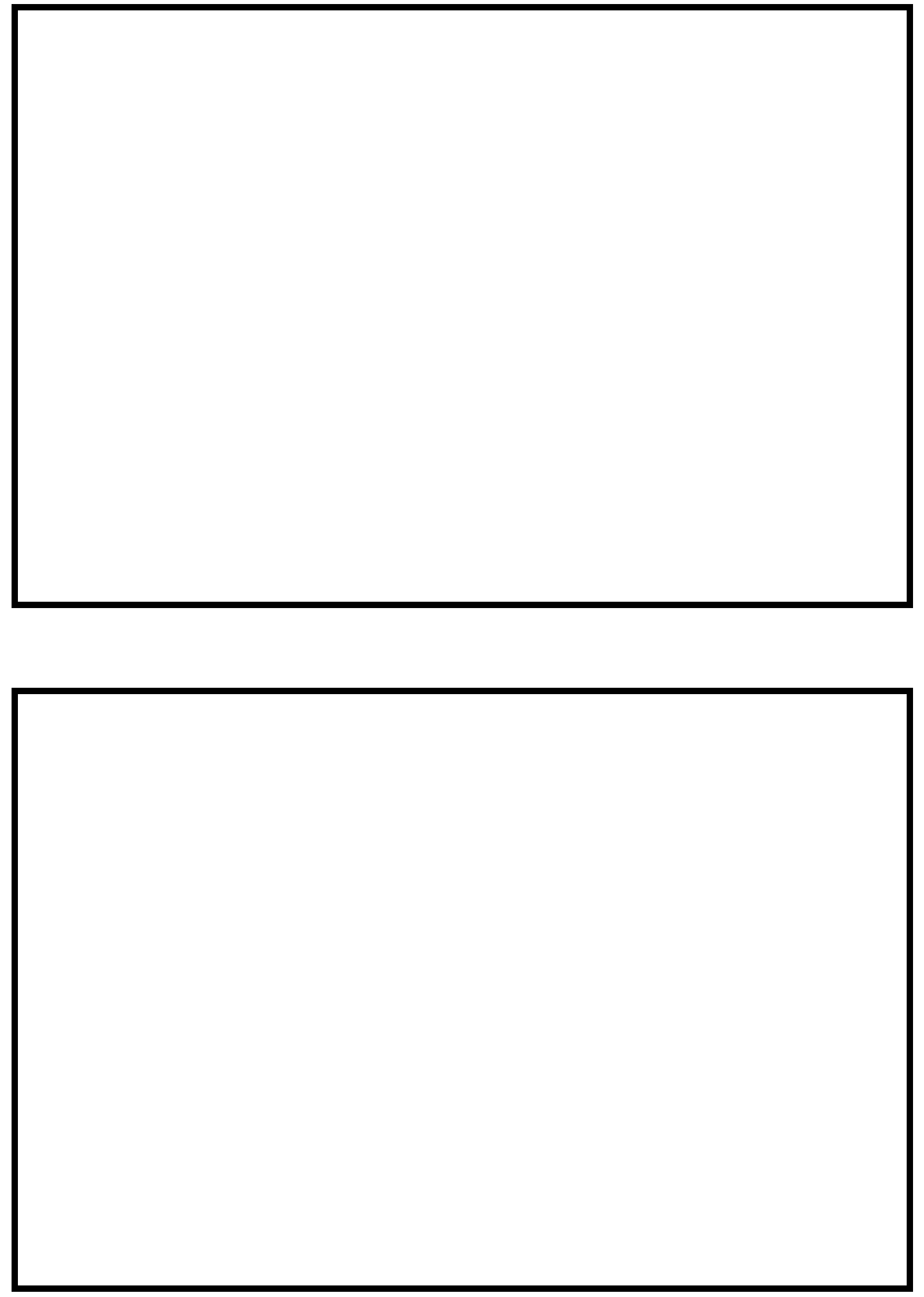


\section{LEVEL II SUMMARY}

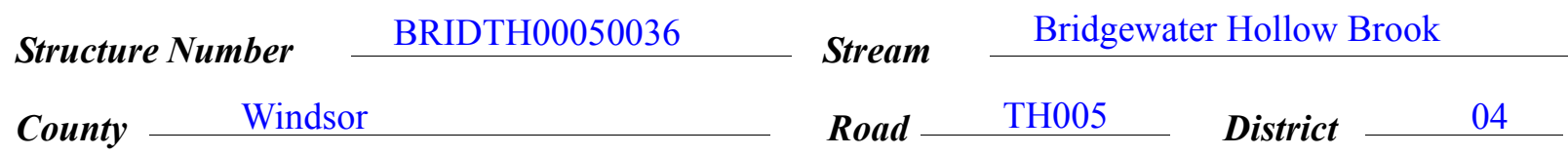

\section{Description of Bridge}

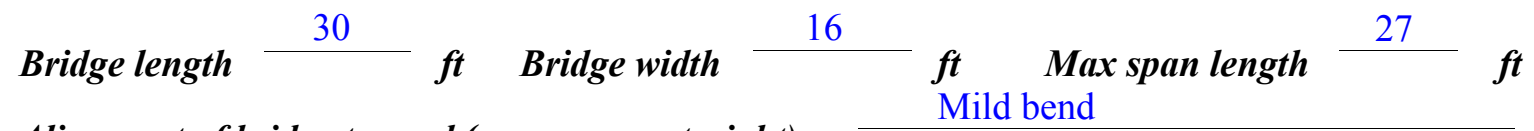

Alignment of bridge to road (on curve or straight)

Abutment type Vertical

Stone fill on abutment?

Yes

Embankment type

None

$11 / 02 / 94$

nacamintion af atoma fill

Drto nf incnortinn
Sparse type-2 along both abutments, both upstream wingwalls, and the downstream left wingwall. Type-1 along the downstream right wingwall.

Abutments and wingwalls are concrete.

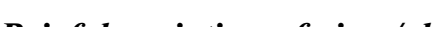

\section{Y \\ 30}

Is bridge skewed to flood flow according to Y ' survey? Angle

There is a mild_channel bend through the reach.

Debris accumulation on bridge at time of Level I or Level II site visit:

\begin{tabular}{|c|c|c|c|}
\hline & $\begin{array}{c}\text { Date of insnortion } \\
\underline{11 / 02 / 94}\end{array}$ & $\begin{array}{l}\text { Percent of alommal } \\
\text { blocked inorizontatly }\end{array}$ & $\begin{array}{l}\text { Percent of } 0 \\
\text { blocked verticatty }\end{array}$ \\
\hline & $11 / 02 / 94$ & -- & -- \\
\hline & Moderate. & & \\
\hline
\end{tabular}

\section{Potential for debris}

Bridgewater Hollow Brook's confluence with the North Branch of the Ottauquechee River is 95 Doscriho anv foaturos noar ar at tho hridoo that mav, affort flow, (includo ahsorvation dato) feet downstream of the bridge. 


\section{Description of the Geomorphic Setting}

General topography The channel is located in a narrow, incised, upland valley.

Geomorphic conditions at bridge site: downstream (DS), upstream (US)

Date of inspection $\quad 11 / 02 / 95$

DS left: $\quad$ Moderately sloping bank

DS right: $\quad$ Moderately sloping bank

US left: $\quad$ Moderately sloping bank

US right: $\quad$ Steep valley wall

\section{Description of the Channel}

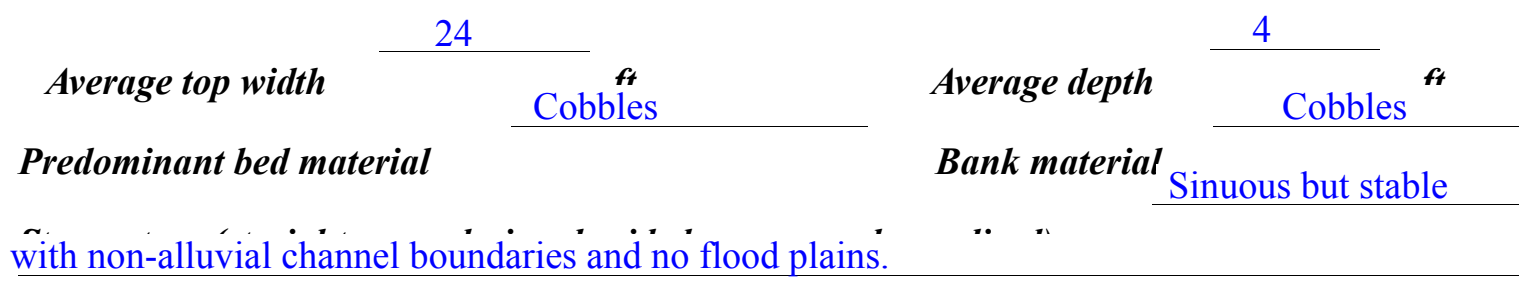

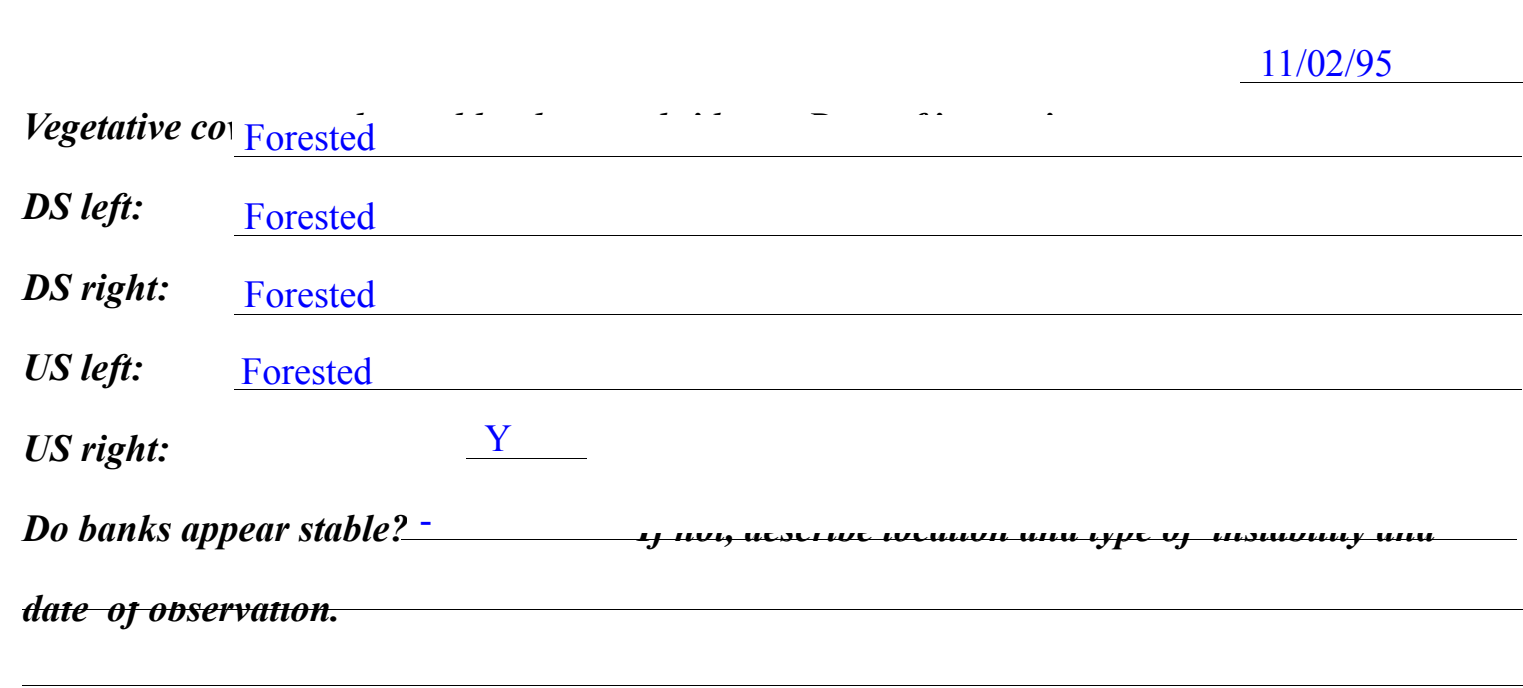

\section{November 2, 1994--}

None.

Describe any obstructions in channel and date of observation. 


\section{Hydrology}

Drainage area $\stackrel{3.60}{\boldsymbol{m i}^{2}}$

Percentage of drainage area in physiographic provinces: (approximate)

Physiographic province/section New England / Green Mountain
Percent of drainage area 100
Is drainage area considered rural or urban?
Rural urbanization: None.
Describe any significant

Is there a USGS gage on the stream of interest?

USGS gage description

USGS gage number

Gage drainage area $m i^{2}$

No

Is there a lake/p

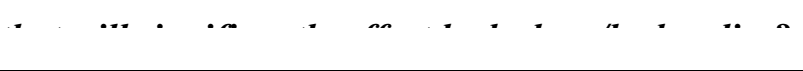

\begin{tabular}{llrl}
1,150 & \multicolumn{2}{c}{ Calculated Discharges } & 1,620 \\
& $f t^{3} / \mathrm{s}$ & $\mathbf{Q 5 0 0}$ & $\mathrm{ft} / \mathrm{s}$
\end{tabular}

The 100- and 500-year discharges are based on a

drainage area relationship [(3.6/4.4)exp 0.7] with bridge number 32 in Bridgewater. Bridge number 32 crosses the North Branch of the Ottauquechee River and has 100-year discharge estimate available from the VTAOT database (VTAOT, written communication, May, 1995). The 500 -year discharge at bridge 32 was estimated by multiplying the Q100 by 1.7 (Richardson and others, 1993). The drainage area above bridge number 32 is 4.4 square miles. 


\section{Description of the Water-Surface Profile Model (WSPRO) Analysis}

Datum for WSPRO analysis (USGS survey, sea level, VTAOT plans)

USGS survey

Datum tie between USGS survey and VTAOT plans

None

Description of reference marks used to determine USGS datum. $\quad$ RM1 is a chiseled X on

top of the downstream end of the left abutment (elev. $498.54 \mathrm{ft}$, arbitrary datum). RM2 is a

chiseled X on top of the upstream end of the right abutment (elev. $500.11 \mathrm{ft}$, arbitrary datum).

\section{Cross-Sections Used in WSPRO Analysis}

\begin{tabular}{|c|c|c|c|}
\hline${ }^{1}$ Cross-section & $\begin{array}{c}\text { Section } \\
\text { Reference } \\
\text { Distance } \\
(\text { SRD) in feet }\end{array}$ & $\begin{array}{c}{ }^{2} \text { Cross-section } \\
\text { development }\end{array}$ & Comments \\
\hline EXITX & -44 & 1 & Exit section \\
\hline FULLV & 0 & 2 & $\begin{array}{l}\text { Downstream Full-valley } \\
\text { section (Templated from } \\
\text { EXITX) }\end{array}$ \\
\hline BRIDG & 0 & 1 & Bridge section \\
\hline RDWAY & 8 & 1 & Road Grade section \\
\hline APPRO & 41 & 2 & $\begin{array}{l}\text { Modelled Approach sec- } \\
\text { tion (Templated from } \\
\text { APTEM) }\end{array}$ \\
\hline APTEM & 66 & 1 & $\begin{array}{l}\text { Approach section as sur- } \\
\text { veyed (Used as a tem- } \\
\text { plate) }\end{array}$ \\
\hline
\end{tabular}

${ }^{1}$ For location of cross-sections see plan-view sketch included with Level I field form, Appendix E.

For more detail on how cross-sections were developed see WSPRO input file. 


\section{Data and Assumptions Used in WSPRO Model}

Hydraulic analyses of the reach were done by use of the Federal Highway Administration's WSPRO step-backwater computer program (Shearman and others, 1986, and Shearman, 1990). The analysis reported herein reflect conditions existing at the site at the time of the study. Furthermore, in the development of the model it was necessary to assume no accumulation of debris or ice at the site. Results of the hydraulic model are presented in the Bridge Hydraulic Summary, Appendix B, and figure 7.

Channel roughness factors (Manning's " $n$ ") used in the hydraulic model were estimated using field inspections at each cross section following the general guidelines described by Arcement and Schneider (1989). Final adjustments to the values were made during the modelling of the reach. Channel " $\mathrm{n}$ " values for the reach ranged from 0.060 to 0.065 , and overbank " $\mathrm{n}$ " values ranged from 0.040 to 0.090 .

Normal depth at the exit section (EXITX) was assumed as the starting water surface. This depth was computed by use of the slope-conveyance method outlined in the user's manual for WSPRO (Shearman, 1990). The slope used was $0.0285 \mathrm{ft} / \mathrm{ft}$ which was determined from surveyed thalweg points downstream of the structure.

The surveyed approach section (APTEM) was moved along the approach channel slope $(0.054 \mathrm{ft} / \mathrm{ft})$ to establish the modelled approach section (APPRO), one bridge length upstream of the upstream face as recommended by Shearman and others (1986). This approach also provides a consistent method for determining scour variables.

For both the 100- and 500-year discharges, flow overtopped the deck. The incipient overtopping discharge was $911 \mathrm{cfs}$. 


\section{Bridge Hydraulics Summary}

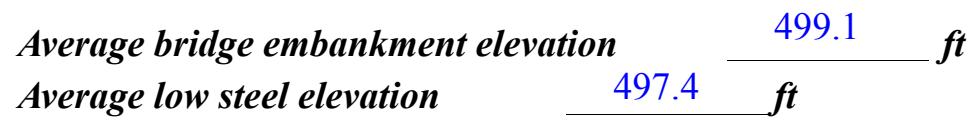

$$
\text { 100-year discharge } \quad 1,150 \quad \mathrm{ft}^{3} / \mathrm{s}
$$

Water-surface elevation in bridge opening $\quad 497.7 \quad f t$

Road overtopping? __ Y Discharge over road _ $\quad 74, \ldots$ s

\begin{tabular}{llll} 
Area of flow in bridge opening & $126 \quad \boldsymbol{f t}^{2}$ & \\
\cline { 2 - 3 } Average velocity in bridge opening & 8.6 & $\boldsymbol{f t} / \mathrm{s}$
\end{tabular}

$\begin{array}{llll}\text { Maximum WSPRO tube velocity at bridge } & 11.9 \mathrm{ft} / \mathrm{s}\end{array}$

Water-surface elevation at Approach section with bridge 499.3

Water-surface elevation at Approach section without bridge $\quad$ 498.1

Amount of backwater caused by bridge $\quad 1.2$ it

500-year discharge $\quad 1,620 \quad \mathrm{ft}^{3} / \mathrm{s}$

Water-surface elevation in bridge opening $\quad 498.0 \mathrm{ft}$

Road overtopping? ___ Y Discharge over road__ $261, \mathrm{~J}$

Area of flow in bridge opening $\quad 126 \quad \mathrm{ft}^{2}$

Average velocity in bridge opening $10.8 \mathrm{ft} / \mathrm{s}$

Maximum WSPRO tube velocity at bridge 12.9 's

Water-surface elevation at Approach section with bridge 500.2

Water-surface elevation at Approach section without bridge $\quad 499.2$

Amount of backwater caused by bridge 1.0 .

Incipient overtopping discharge $\quad 911 \quad \mathrm{ft}^{3} / \mathrm{s}$

Water-surface elevation in bridge opening $\quad 497.4 \quad t$

Area of flow in bridge opening $\quad 123 \quad \mathrm{ft}^{2}$

Average velocity in bridge opening $\quad 7.4 \quad \mathrm{ft} / \mathrm{s}$

Maximum WSPRO tube velocity at bridge $\quad 10.5 \mathrm{ft} / \mathrm{s}$

Water-surface elevation at Approach section with bridge

Water-surface elevation at Approach section without bridge

Amount of backwater caused by bridge $\quad 1.2$,

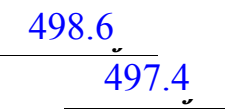




\section{Scour Analysis Summary}

\section{Special Conditions or Assumptions Made in Scour Analysis}

Scour depths were computed using the general guidelines described in Hydraulic Engineering Circular 18 (Richardson and others, 1993). Scour depths were calculated assuming an infinite depth of erosive material and a homogeneous particle-size distribution. The results of the scour analysis are presented in tables 1 and 2 and a graph of the scour depths is presented in figure 8 .

Contraction scour was computed by use of the Chang pressure-flow scour equation (Richardson and others, 1995, p. 145-146). For each of the modelled discharges, there was orifice flow at the bridge. Contraction scour at bridges with orifice flow is best estimated by use of the Chang pressure-flow scour equation (oral communication, J. Sterling Jones, October 4, 1996). The results of Laursen's clear-water contraction scour equation (Richardson and others, 1993, p. 35, equation 18) were also computed and can be found in appendix F. For contraction scour computations, the average depth in the contracted section (AREA/TOPWIDTH) is subtracted from the depth of flow computed by the scour equation (Y2) to determine the actual amount of scour.

Abutment scour was computed by use of the Froehlich equation (Richardson and others, 1993, p. 49, equation 24). The Froehlich equation gives "excessively conservative estimates of scour depths" (Richardson and others, 1993, p. 48). Variables for the Froehlich equation include the Froude number of the flow approaching the embankments, the length of the embankment blocking flow, and the depth of flow approaching the embankment less any roadway overtopping. The 500-year discharge resulted in the worst case computed abutment scour. 


\section{Scour Results}

100-yr discharge 500-yrdischarge

Incipient

Contraction scour:

(Scour depths in feet)

Main channel

Live-bed scour

Clear-water scour

Depth to armoring

Left overbank

Right overbank

Local scour:

Abutment scour

4.9

7.0

5.2

Left abutment

$6.2-$

6.9-

5.5-

\section{Right abutment}

Pier scour

Pier 1

Pier 2

Pier 3

Abutments:

Left abutment

Right abutment

Piers:

Pier 1

Pier 2

\section{Riprap Sizing}

overtopping discharge 


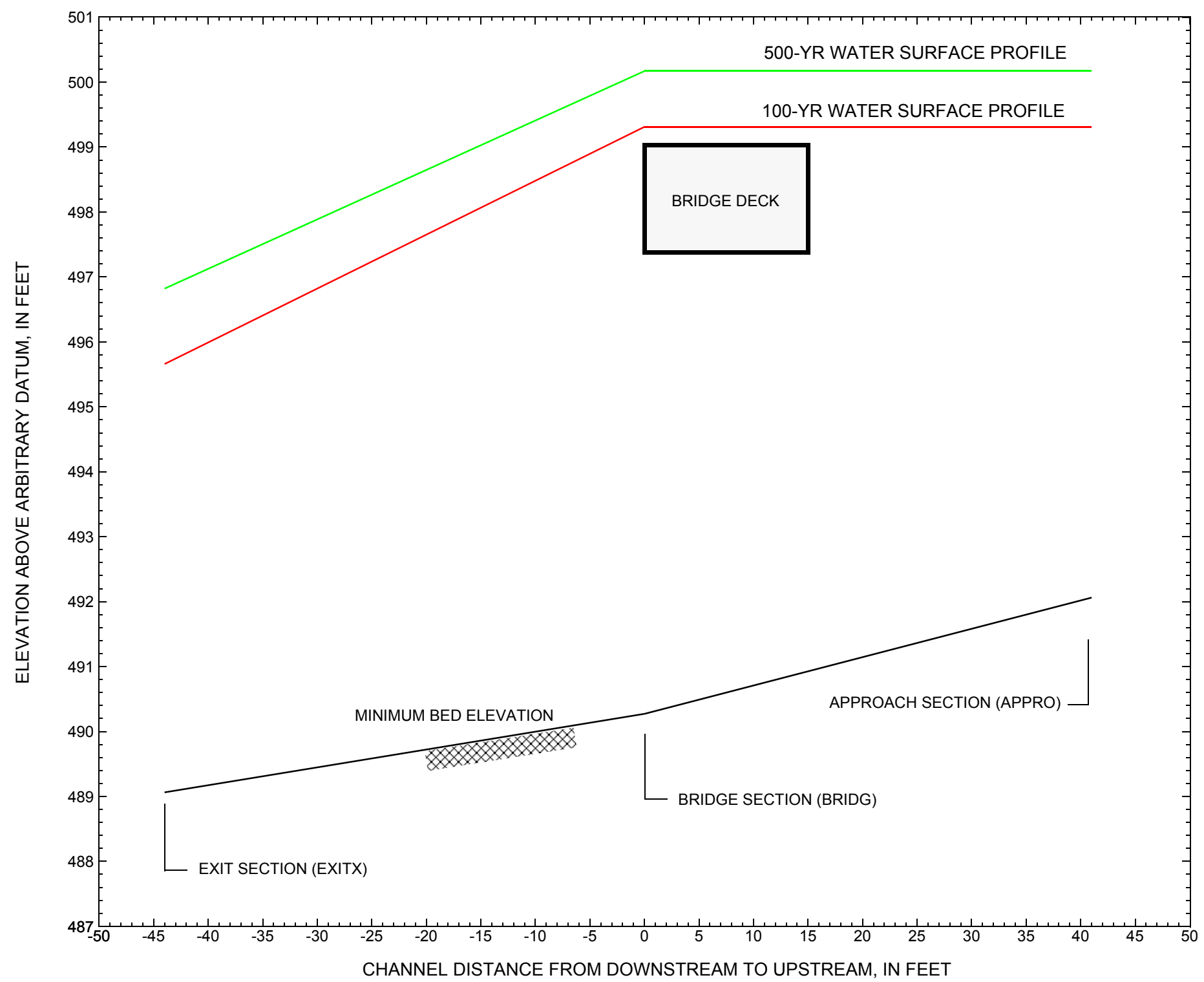

Figure 7. Water-surface profiles for the 100- and 500-yr discharges at structure BRIDTH00050036 on town highway 5, crossing Bridgewater Hollow Brook, Bridgewater, Vermont. 


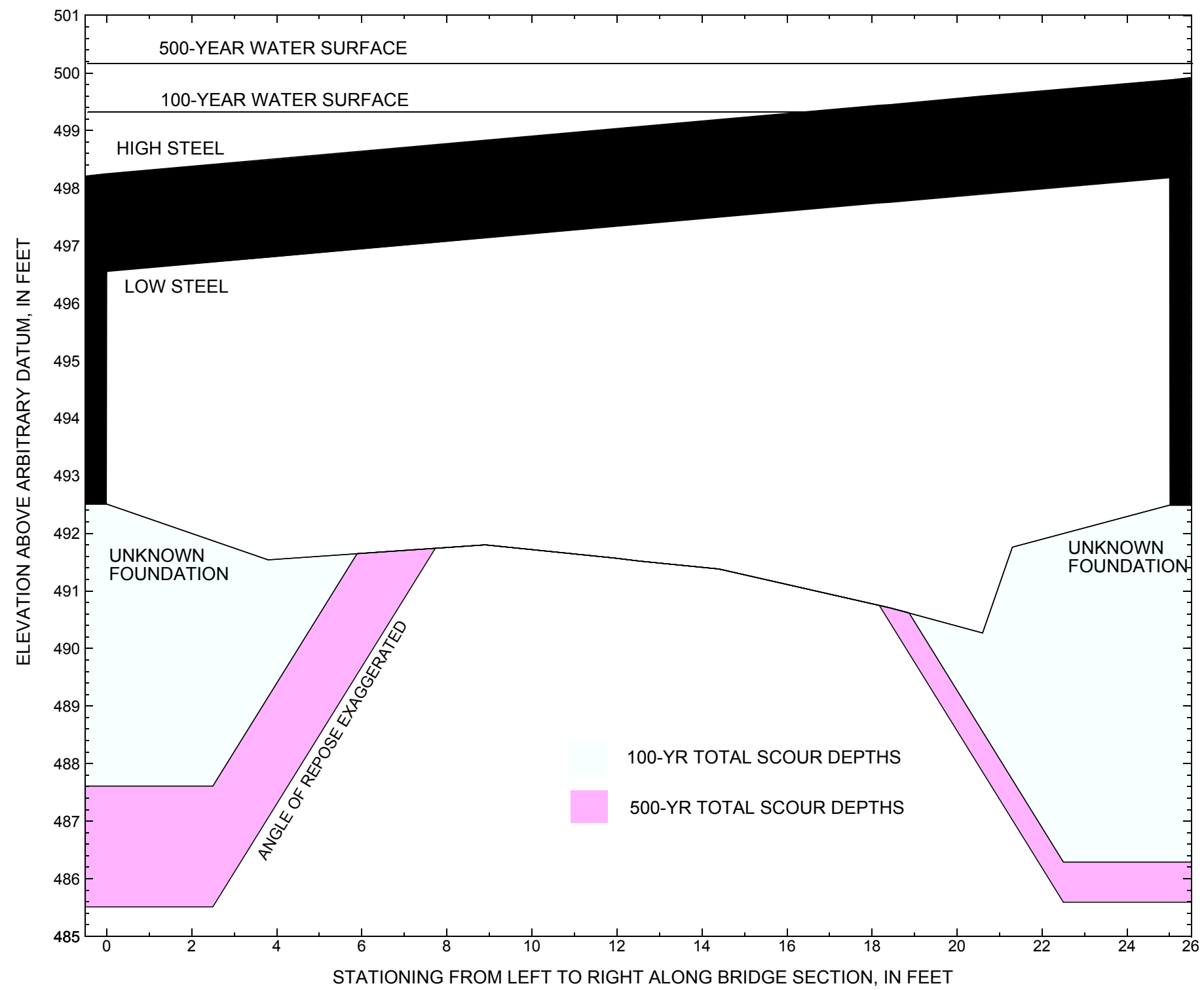

Figure 8. Scour elevations for the 100-yr and 500-yr discharges at structure BRIDTH00050036 on town highway 5, crossing Bridgewater Hollow Brook, Bridgewater, Vermont. 
Table 1. Remaining footing/pile depth at abutments for the 100-year discharge at structure BRIDTH00050036 on Town Highway 5, crossing Bridgewater Hollow Brook, Bridgewater, Vermont.

[VTAOT, Vermont Agency of Transportation; --,no data]

\begin{tabular}{|c|c|c|c|c|c|c|c|c|c|c|c|}
\hline Description & Station $^{1}$ & $\begin{array}{l}\text { VTAOT } \\
\text { minimum } \\
\text { low-chord } \\
\text { elevation } \\
\text { (feet) }\end{array}$ & $\begin{array}{c}\text { Surveyed } \\
\text { minimum } \\
\text { low-chord } \\
\text { elevation }{ }^{2} \\
\text { (feet) }\end{array}$ & $\begin{array}{c}\text { Bottom of } \\
\text { footing } \\
\text { elevation } \\
\text { (feet) }\end{array}$ & $\begin{array}{c}\text { Channel } \\
\text { elevation at } \\
\text { abutment/ } \\
\text { pier }^{2} \\
\text { (feet) }\end{array}$ & $\begin{array}{l}\text { Contraction } \\
\text { scour depth } \\
\text { (feet) }\end{array}$ & $\begin{array}{l}\text { Abutment } \\
\text { scour } \\
\text { depth } \\
\text { (feet) }\end{array}$ & $\begin{array}{l}\text { Pier } \\
\text { scour } \\
\text { depth } \\
\text { (feet) }\end{array}$ & $\begin{array}{l}\text { Depth of } \\
\text { total scour } \\
\text { (feet) }\end{array}$ & $\begin{array}{c}\text { Elevation of } \\
\text { scour }^{2} \\
\text { (feet) }\end{array}$ & $\begin{array}{c}\text { Remaining } \\
\text { footing/pile } \\
\text { depth } \\
\text { (feet) }\end{array}$ \\
\hline \multicolumn{12}{|c|}{100 -yr. discharge is 1,150 cubic-feet per second } \\
\hline Left abutment & 0.0 & -- & 496.73 & -- & 492.5 & 0.0 & 4.9 & -- & 4.9 & 487.6 & -- \\
\hline Right abutment & 25.0 & -- & 498.03 & -- & 492.5 & 0.0 & 6.2 & -- & 6.2 & 486.3 & -- \\
\hline
\end{tabular}

1. Measured along the face of the most constricting side of the bridge.

2. Arbitrary datum for this study.

Table 2. Remaining footing/pile depth at abutments for the 500-year discharge at structure BRIDTH00050036 on Town Highway 5, crossing Bridgewater Hollow Brook, Bridgewater, Vermont.

[VTAOT, Vermont Agency of Transportation; --, no data]

\begin{tabular}{|c|c|c|c|c|c|c|c|c|c|c|c|}
\hline Description & Station $^{1}$ & $\begin{array}{l}\text { VTAOT } \\
\text { minimum } \\
\text { low-chord } \\
\text { elevation } \\
\text { (feet) }\end{array}$ & $\begin{array}{c}\text { Surveyed } \\
\text { minimum } \\
\text { low-chord } \\
\text { elevation }{ }^{2} \\
\text { (feet) }\end{array}$ & $\begin{array}{c}\text { Bottom of } \\
\text { footing } \\
\text { elevation } \\
\text { (feet) }\end{array}$ & $\begin{array}{c}\text { Channel } \\
\text { elevation at } \\
\text { abutment/ } \\
\text { pier }^{2} \\
\text { (feet) }\end{array}$ & $\begin{array}{l}\text { Contraction } \\
\text { scour depth } \\
\text { (feet) }\end{array}$ & $\begin{array}{l}\text { Abutment } \\
\text { scour } \\
\text { depth } \\
\text { (feet) }\end{array}$ & $\begin{array}{l}\text { Pier } \\
\text { scour } \\
\text { depth } \\
\text { (feet) }\end{array}$ & $\begin{array}{l}\text { Depth of } \\
\text { total scour } \\
\quad \text { (feet) }\end{array}$ & $\begin{array}{c}\text { Elevation of } \\
\text { scour }^{2} \\
\text { (feet) }\end{array}$ & $\begin{array}{c}\text { Remaining } \\
\text { footing/pile } \\
\text { depth } \\
\text { (feet) }\end{array}$ \\
\hline \multicolumn{12}{|c|}{500 -yr. discharge is 1,620 cubic-feet per second } \\
\hline Left abutment & 0.0 & -- & 496.73 & -- & 492.5 & 0.0 & 7.0 & -- & 7.0 & 485.5 & -- \\
\hline Right abutment & 25.0 & -- & 498.03 & -- & 492.5 & 0.0 & 6.9 & -- & 6.9 & 485.6 & -- \\
\hline
\end{tabular}

1. Measured along the face of the most constricting side of the bridge.

2. Arbitrary datum for this study. 
Arcement, G.J., Jr., and Schneider, V.R., 1989, Guide for selecting Manning's roughness coefficients for natural channels and flood plains: U.S. Geological Survey Water-Supply Paper 2339, 38 p.

Barnes, H.H., Jr., 1967, Roughness characteristics of natural channels: U.S. Geological Survey Water-Supply Paper 1849, 213 p.

Brown, S.A. and Clyde, E.S., 1989, Design of riprap revetment: Federal Highway Administration Hydraulic Engineering Circular No. 11, Publication FHWA-IP-89-016, 156 p.

Federal Emergency Management Agency, 1980, Flood Insurance Study, Town of Bridgewater, Windsor County, Vermont: Washington, D.C., January 1980.

Federal Highway Administration, 1983, Runoff estimates for small watersheds and development of sound design: Federal Highway Administration Report FHWA-RD-77-158

Froehlich, D.C., 1989, Local scour at bridge abutments in Ports, M.A., ed., Hydraulic Engineering--Proceedings of the 1989 National Conference on Hydraulic Engineering: New York, American Society of Civil Engineers, p. 13-18.

Hayes, D.C.,1993, Site selection and collection of bridge-scour data in Delaware, Maryland, and Virginia: U.S. Geological Survey Water-Resources Investigation Report 93-4017, 23 p.

Johnson, C.G. and Tasker, G.D.,1974, Progress report on flood magnitude and frequency of Vermont streams: U.S. Geological Survey Open-File Report 74-130, 37 p.

Lagasse, P.F., Schall, J.D., Johnson, F., Richardson, E.V., Richardson, J.R., Chang, F., 1991, Stream Stability at Highway Structures: Federal Highway Administration Hydraulic Engineering Circular No. 20, Publication FHWA-IP-90-014, $195 \mathrm{p}$.

Laursen, E.M., 1960, Scour at bridge crossings: Journal of the Hydraulics Division, American Society of Civil Engineers, v. 86, no. HY2, p. 39-53.

Richardson, E.V., and Davis, S.R., 1995, Evaluating scour at bridges: Federal Highway Administration Hydraulic Engineering Circular No. 18, Publication FHWA-IP-90-017, 204p.

Richardson, E.V., Harrison, L.J., Richardson, J.R., and Davis, S.R., 1993, Evaluating scour at bridges: Federal Highway Administration Hydraulic Engineering Circular No. 18, Publication FHWA-IP-90-017, 131 p.

Richardson, E.V., Simons, D.B., and Julien, P.Y., 1990, Highways in the river environment: Federal Highway Administration Publication FHWA-HI-90-016.

Ritter, D.F., 1984, Process Geomorphology: W.C. Brown Co., Debuque, Iowa, 603 p.

Shearman, J.O., 1990, User's manual for WSPRO--a computer model for water surface profile computations: Federal Highway Administration Publication FHWA-IP-89-027, 187 p.

Shearman, J.O., Kirby, W.H., Schneider, V.R., and Flippo, H.N., 1986, Bridge waterways analysis model; research report: Federal Highway Administration Publication FHWA-RD-86-108, 112 p.

U.S. Department of Transportation, 1993, Stream stability and scour at highway bridges, Participant Workbook: Federal Highway Administration Publication FHWA HI-91-011.

U.S. Geological Survey, 1966, Delectable Mountain, Vermont 7.5 Minute Series quadrangle map: U.S. Geological Survey Topographic Maps, Photoinspected 1983, Scale 1:24,000. 


\section{APPENDIX A: \\ WSPRO INPUT FILE}




\section{APPENDIX B: \\ WSPRO OUTPUT FILE}




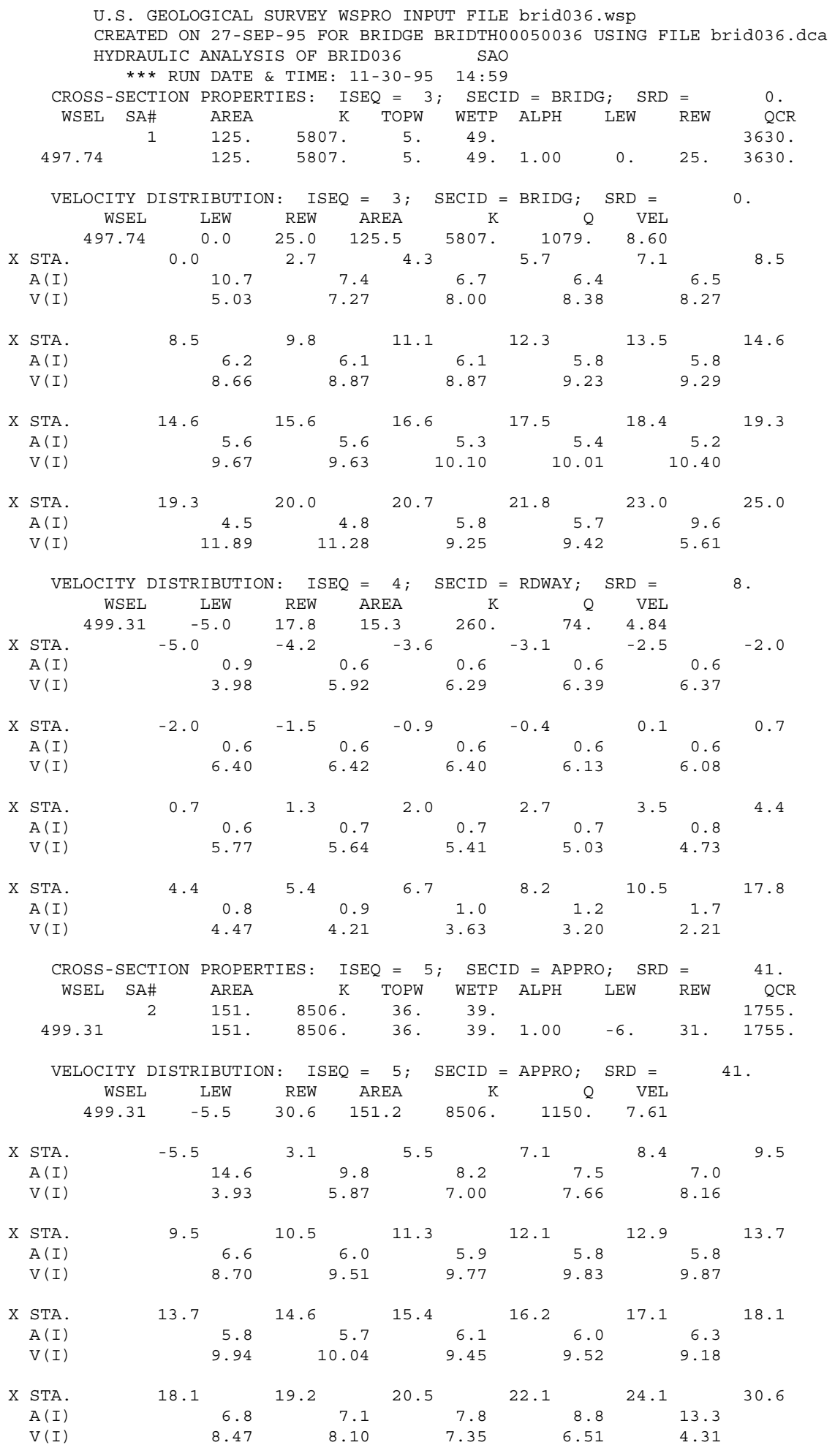


WSPRO OUTPUT FILE (continued)

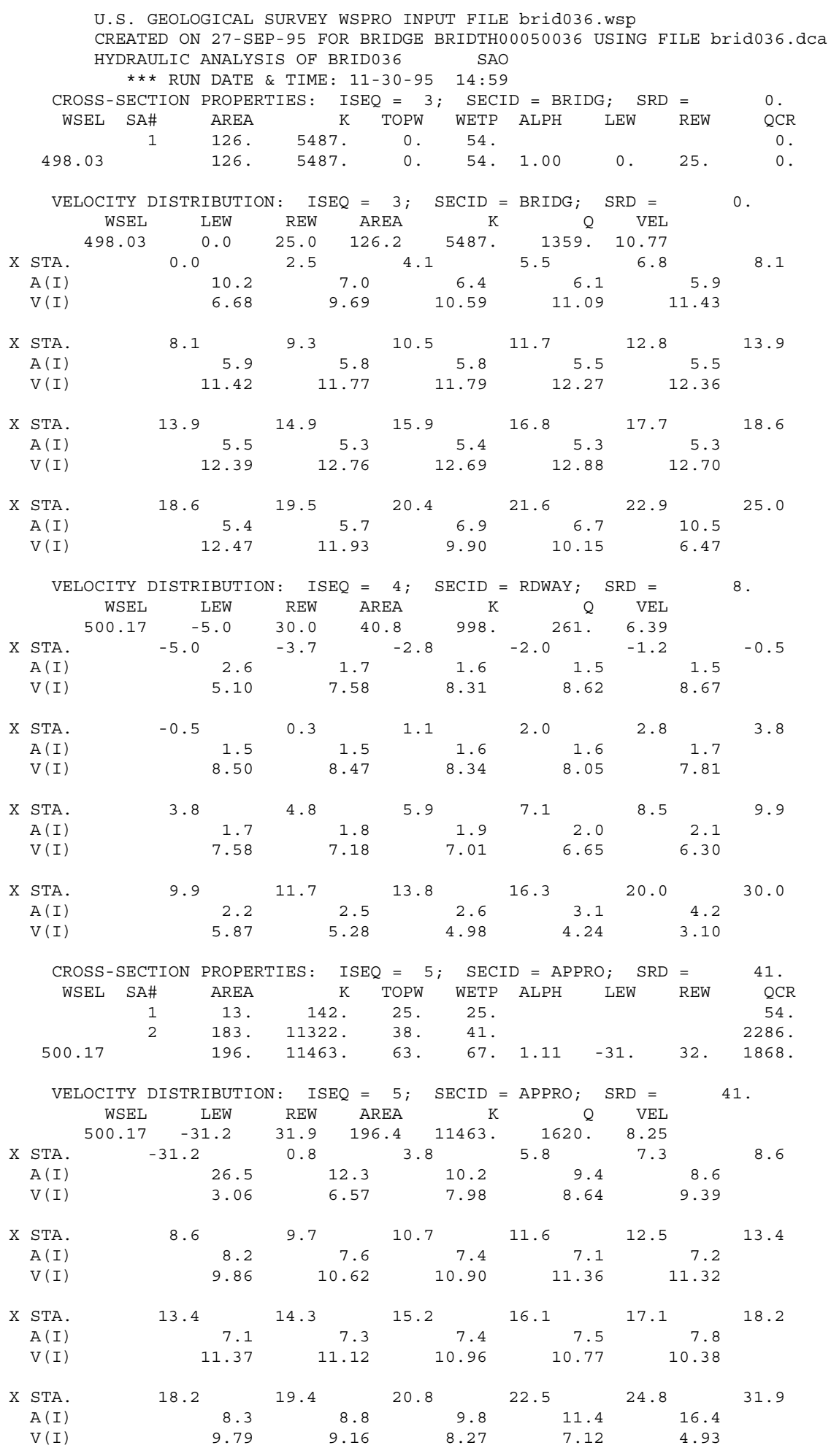


WSPRO OUTPUT FILE (continued)

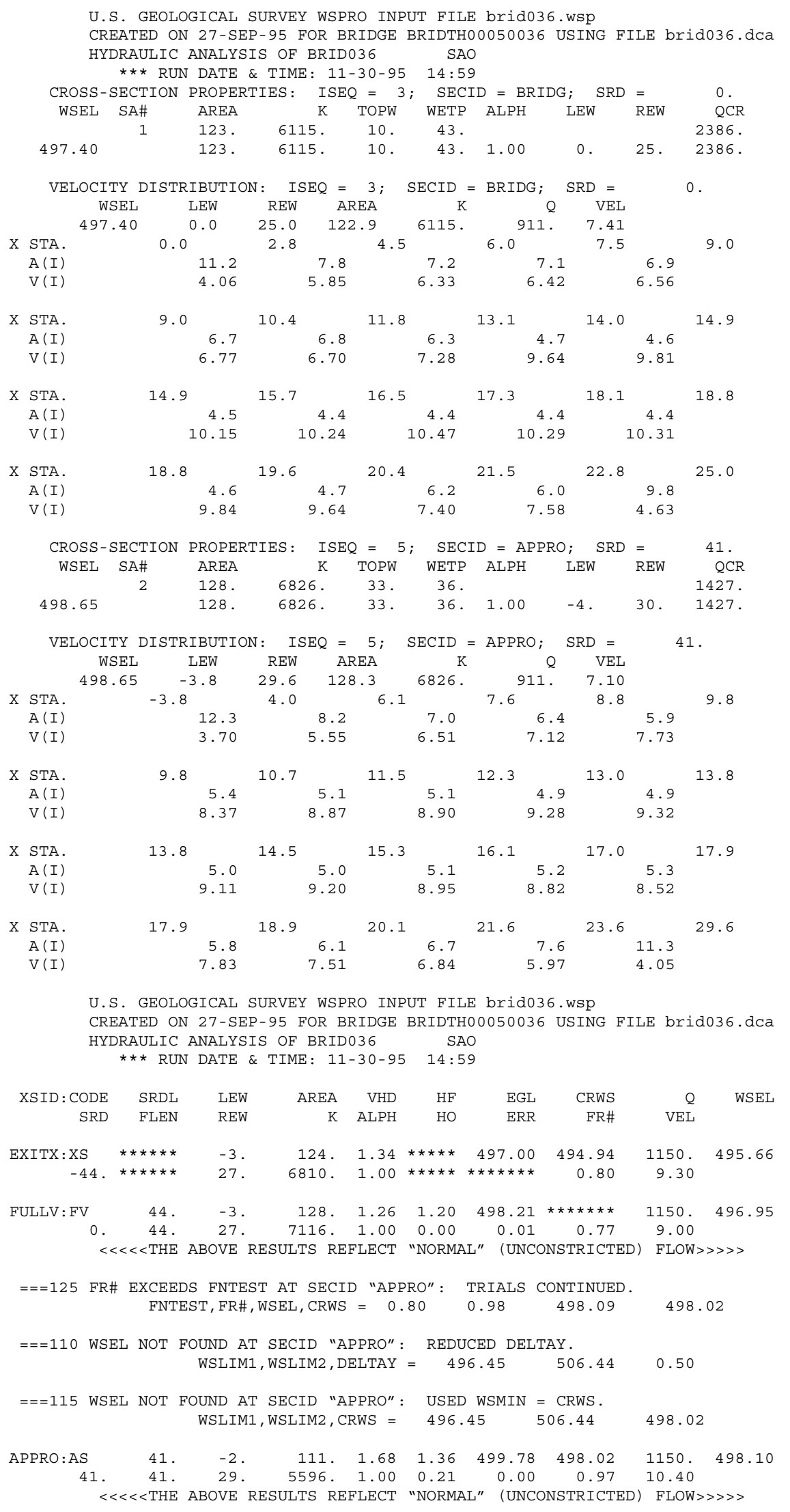




\section{WSPRO OUTPUT FILE (continued)}

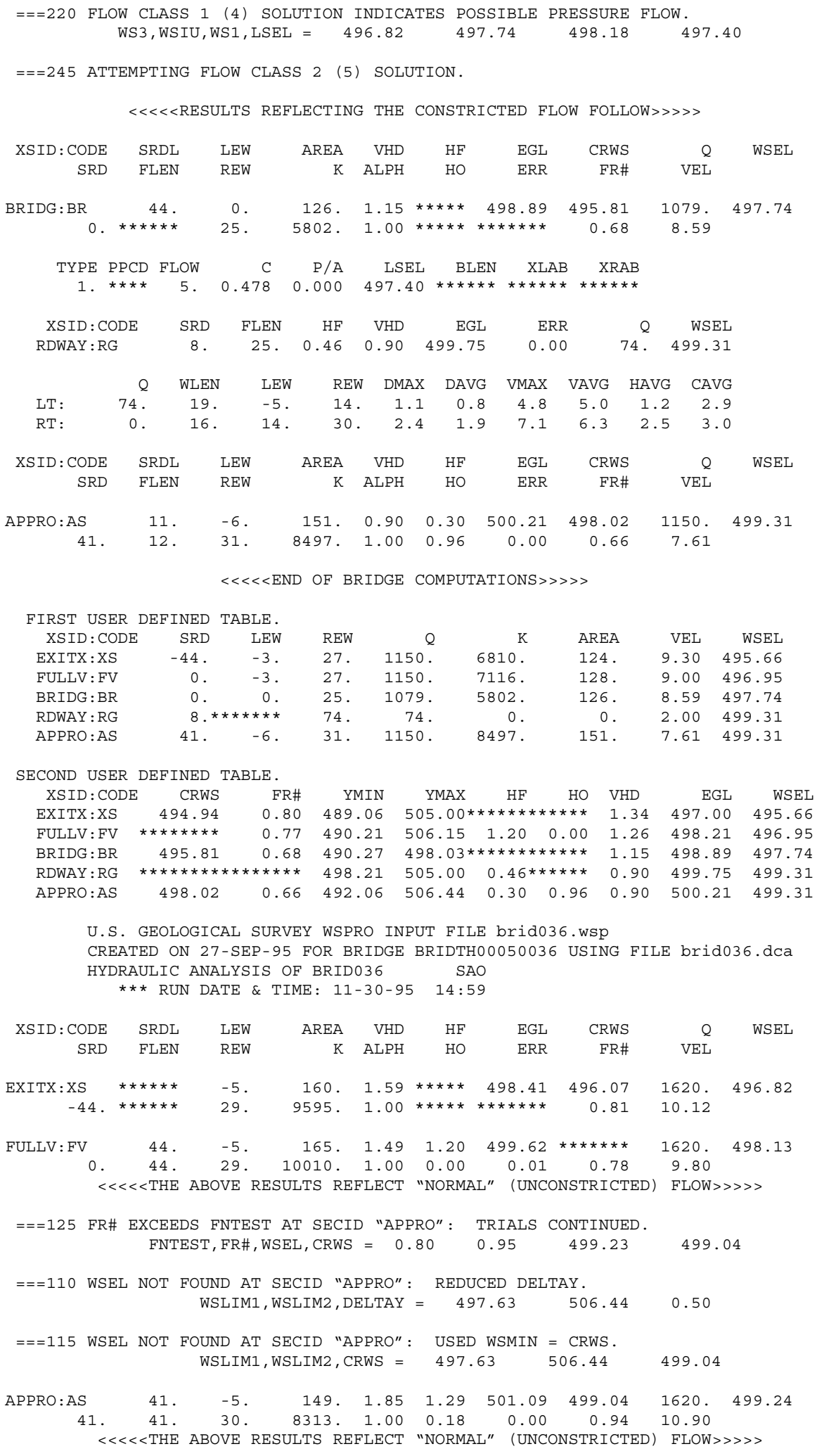


WSPRO OUTPUT FILE (continued)

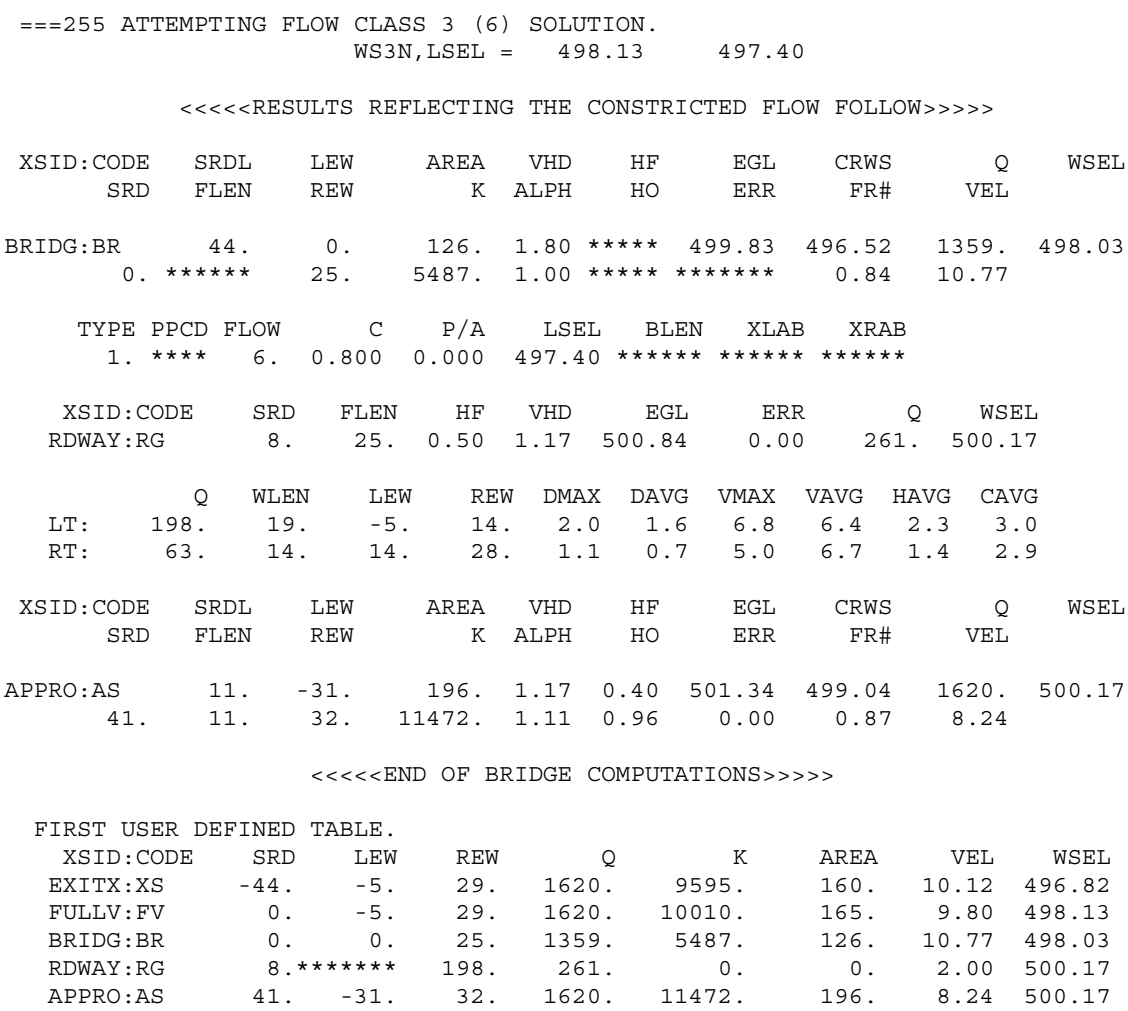

SECOND USER DEFINED TABLE.

$\begin{array}{lcrrrrrrrr}\text { XSID : CODE } & \text { CRWS } & \text { FR\# } & \text { YMIN } & \text { YMAX } & \text { HF } & \text { HO } & \text { VHD } & \text { EGL } & \text { WSEL } \\ \text { EXITX:XS } & 496.07 & 0.81 & 489.06 & 505.00 * * * * * * * * * * * & 1.59 & 498.41 & 496.82 \\ \text { FULLV:FV } & * * * * * * * * & 0.78 & 490.21 & 506.15 & 1.20 & 0.00 & 1.49 & 499.62 & 498.13 \\ \text { BRIDG:BR } & 496.52 & 0.84 & 490.27 & 498.03 * * * * * * * * * * * & 1.80 & 499.83 & 498.03 \\ \text { RDWAY: RG } & * * * * * * * * * * * * * * * & 498.21 & 505.00 & 0.50 * * * * * * & 1.17 & 500.84 & 500.17 \\ \text { APPRO:AS } & 499.04 & 0.87 & 492.06 & 506.44 & 0.40 & 0.96 & 1.17 & 501.34 & 500.17\end{array}$

U.S. GEOLOGICAL SURVEY WSPRO INPUT FILE brid036.wsp

CREATED ON 27-SEP-95 FOR BRIDGE BRIDTH00050036 USING FILE brid036.dCa HYDRAULIC ANALYSIS OF BRID036 SAO

*** RUN DATE \& TIME: 11-30-95 14:59

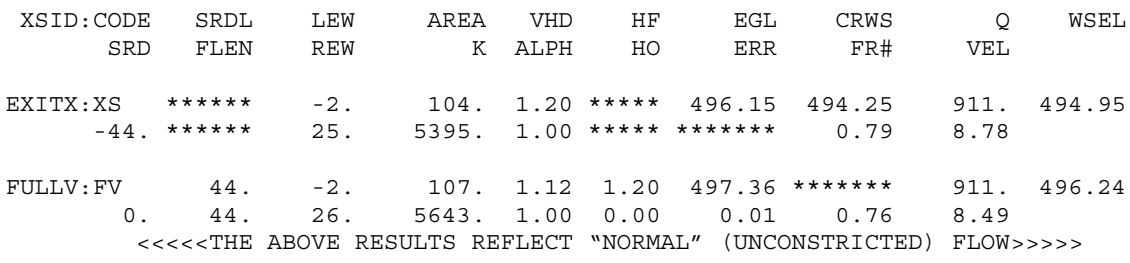

$==125$ FR\# EXCEEDS FNTEST AT SECID "APPRO": TRIALS CONTINUED.

FNTEST, FR\#, WSEL, CRWS $=\begin{array}{cccc}0.80 & 1.00 & 497.42 & 497.40\end{array}$

$==110$ WSEL NOT FOUND AT SECID "APPRO": REDUCED DELTAY.

WSLIM1, WSLIM2, DELTAY $=495.74 \quad 506.44 \quad 0.50$

$==115$ WSEL NOT FOUND AT SECID "APPRO": USED WSMIN = CRWS.

WSLIM1, WSLIM2, CRWS $=495.74 \quad 506.44 \quad 497.40$

$\begin{array}{llllllllll}\text { APPRO : AS } & 41 . & 0 . & 90 . & 1.60 & 1.42 & 499.00 & 497.40 & 911 . & 497.40\end{array}$

41. 41. 28. 4237. $\quad \begin{array}{llllll}\text { 4.00 } & 0.24 & -0.02 & 1.00 & 10.14\end{array}$

$\ll<<<$ THE ABOVE RESULTS REFLECT "NORMAL" (UNCONSTRICTED) FLOW $\gg>>>$ 


\section{WSPRO OUTPUT FILE (continued)}

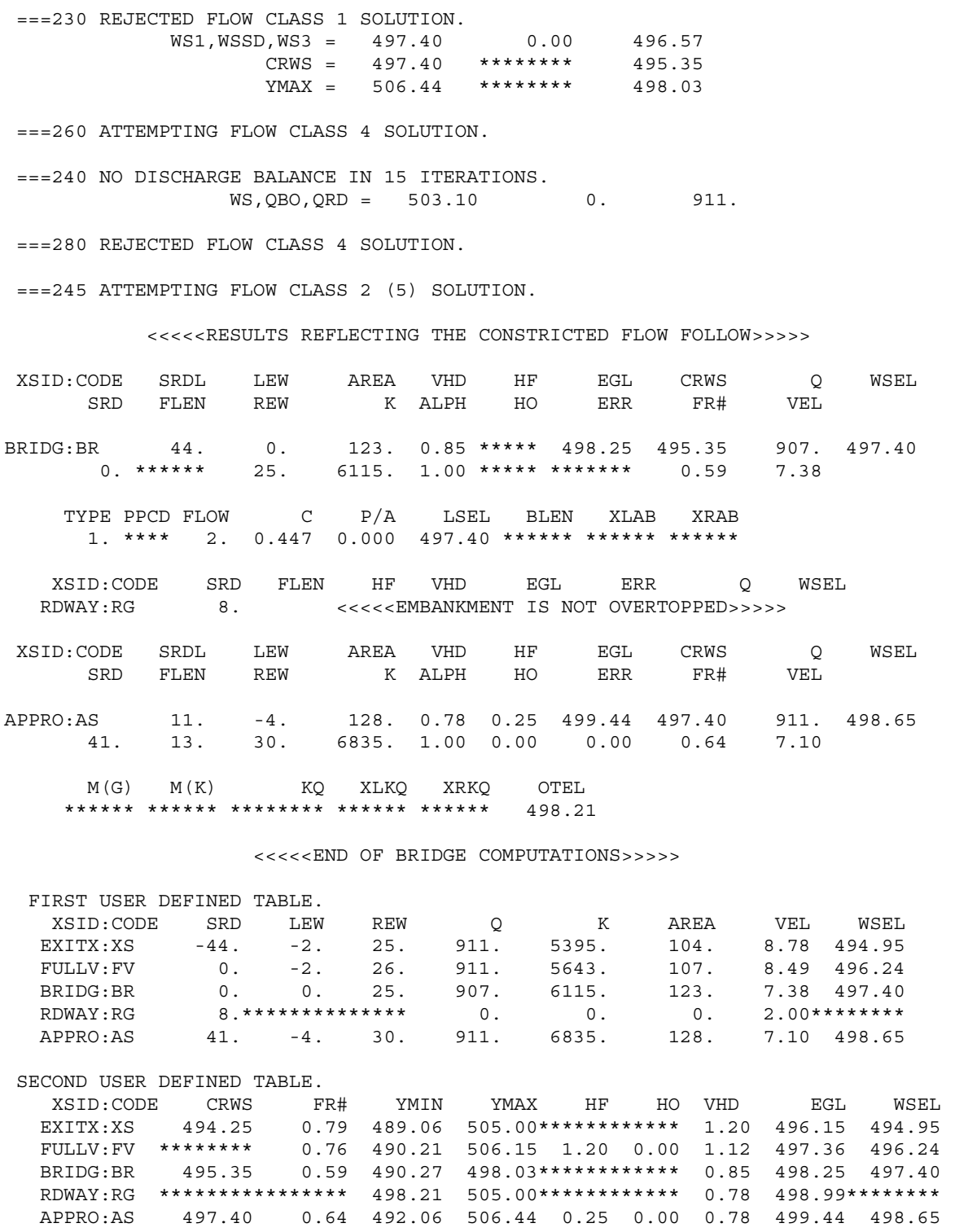




\section{APPENDIX C:}

\section{BED-MATERIAL PARTICAL-SIZE DISTRIBUTION}




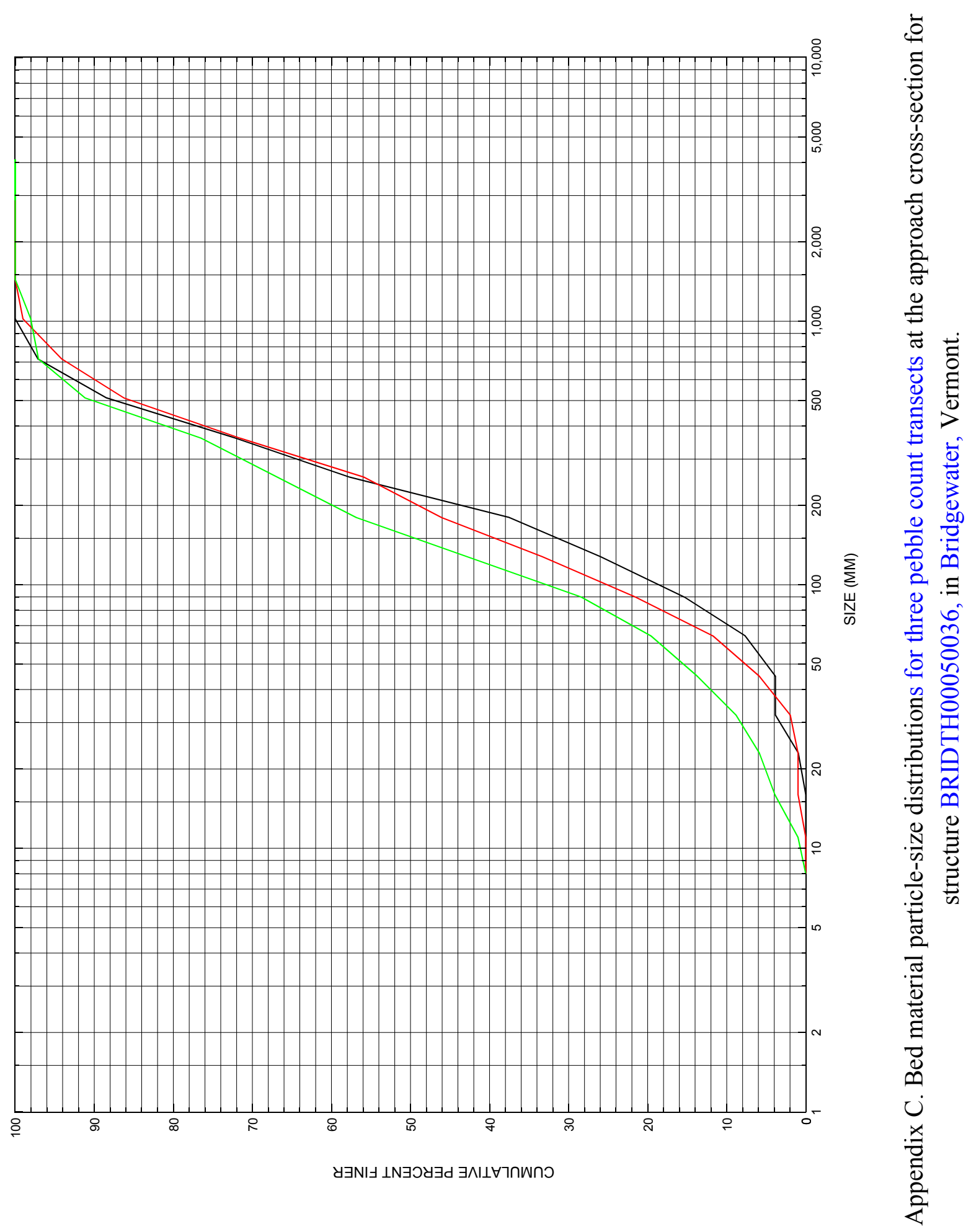




\section{APPENDIX D: \\ HISTORICAL DATA FORM}

